\title{
2 Genre for Social Action: Transforming Worlds Through Genre Awareness and Action
}

\begin{abstract}
Redefining genres as social action in the 1980s has led to understanding that genres reflect, shape, and reinforce worlds through the social actions they define and perform. The critical turn in genre studies in the following decades has led to more awareness of genre's power to shape users unknowingly toward a community's norms and values. This chapter argues for extending that critical awareness to critical action. Genres work not only as social action but for social action. Genres work for social action when people act through them deliberately, consciously, and toward desired social ends. This chapter defines and briefly illustrates four means of using genres for social action: genre mindfulness, genre resistance, genre revision, and genre creation. Critical awareness of those social actions can transform everyday social actions that get things done in the world into powerful actions with social and political purpose, actions meant to alter the world in meaningful and even structural ways.
\end{abstract}

\subsection{Introduction}

This volume demonstrates that genres matter. Genres matter because they carry with them not just conventions but expectations and norms. Genres matter because they shape the people who use them into particular kinds of actors performing particular kinds of actions. Genres matter because people enact not just a genre but its accompanying system, institutional setting, and cultural values. Genres matter because people may use genres without being aware of genres' ability to support or inhibit their motivations and goals; or people may use genres fully aware of how genres can manipulate those who are unaware. Genres matter.

Genres matter in the climate debate - or any debate - because their conventions, norms, actions, systems, and potential invisibility direct the debate in sometimes unnoticed and sometimes unintentional ways. Rhetorical genre studies of the last thirty years has argued that genres are social actions (Miller, 1984) and established that genres are the ways we do things in the world (Freedman \& Medway, 1994). ${ }^{1}$ I am arguing here that, because they are social actions and the ways we do things in the

1 For some overviews, see Devitt (2004b), Martin and Rose (2008), Bawarshi and Reiff (2010), and Auken (2015). This body of scholarship is so large today that references in this essay will represent only a few illustrations for readers who wish to learn more. 
world, genres shape argument, including and perhaps especially politically charged debate. Although genres can become so normalized that their actions are hard to resist $^{2}$, becoming critically aware of genres' effects can lead to more deliberate debate and to more deliberate action. Those who want to make changes in the world need to make those changes against and especially through genres. Genres operate not just as social action but for social action.

To explain and illustrate genres for social action, I briefly review some key principles of rhetorical genre theory, define four ways of using genres for social action, and offer a few examples of genres in action, with particular reference to this volume's topic of climate debate. In the end, I argue for using critical genre awareness to exploit genres' capacities for creating change in order to make a positive difference in our worlds.

\subsection{Genres as Social Actions}

Calling genres social actions originated with Carolyn Miller's now-foundational 1984 article entitled “Genres as Social Action.” Building from rhetorical criticism and especially the insights of Karlyn Kohrs Campbell and Kathleen Hall Jamieson on Form and Genre (1978), Miller articulated a semiotic perspective on genre as combusting form and substance into socially meaningful action. Based on Miller's 1984 article, rhetorical genre studies has connected genres less to textual forms than to rhetorical acts. Genres don't just sit there; they do something.

Early studies of workplaces and professions investigated how genres functioned in communities and systems and explained how genres worked to fulfill the community's purposes ${ }^{3}$. Genres developed out of communities' needs and performed typified actions when the task and situation were perceived to be similar to tasks and situations encountered before. As I concluded in my study of "Intertextuality in Tax Accounting" (1991), all the texts tax accountants produce together "describe a genre system which both delimits and enables its work" (353). The notion of genre systems later developed to account for the interactions of genres both within and across communities, including across multiple activity systems, creating complex interplays of genre sets in the performance of large scale institutional or societal social actions (Bazerman, 1994; Russell, 1997).

2 See, for example, articles in Coe, Lingard, and Teslenko (2002), or, more particularly, Luke (1996), Peters (1997), Fuller and Lee (2002), Paré (2002), Segal (2007), Devitt (2009b), among many more studies of genres' ideological power.

3 For example, Swales, (1990), Devitt (1991), Bhatia (1993), Schryer, 1994; Berkenkotter and Huckin (1995), Artemeva (2009). 
Most of this genre research observed how genres worked in their communities, seeking to understand the genres from the perspective of their users. For example, in my study of tax accountants' genres, I not only examined the sample texts that tax accountants supplied as examples of the kinds of writing they did; I also interviewed the partners and associates to learn how those users categorized those genres, how they learned to write in the genres, and how those genres operated together for them in genre sets and systems (what Charles Bazerman later elaborated in "Systems of Genre” (1994) and Anne Freadman examines more interactively as uptake (1994, 2002)). Genre researchers observed genres in their native habitats, recording what they observed and interpreting those observations through the lens of the participants.

While observing through the eyes of the users led to a much more complex understanding of how genres acted, genre scholarship was missing a much-needed critical perspective. The genres that resulted from fulfilling community purposes became norms - and normalized. For tax accountants, to continue that example, understanding their texts required understanding "their genre systems and their rhetorical situations, their intertextual references and their underlying epistemologies, their uses and their community functions" (354). The critical perspective on genre that is now so widespread took some time to develop within genre studies, but it has become well established in theory, research, and pedagogy. In the past twenty or more years, genre scholars have built on the turn to genres as rhetorical rather than formulaic and as action rather than form to see genres as not simply functional and community-based but ideological and hegemonic ${ }^{4}$.

The happy-sounding "communities" in which genres reside are sites of power and privilege, insiders and outsiders, gatekeeping and access. To succeed in their profession, the novice tax accountants I studied had to learn to write tax memoranda that did what the senior partners expected; had to learn how to distinguish their legal liability in opinion letters from other letters to clients; had to learn when to use memoranda for the files to provide a record of phone conversations and meetings. As Miller (1984) concluded, "what we learn when we learn a genre is not just a pattern of forms or even a method of achieving our own ends. We learn, more importantly, what ends we may have" (165). Though her conclusion at the time may have seemed simply descriptive, today that insight leads to the power of genres to shape novices in the master's image. Genres used in schools act similarly as gatekeepers, shaping how students and teachers should act, thereby defining who belongs and who doesn't. Recognizing that power of genres to define community membership, genre scholars like Ann Johns (1997), Ken Hyland (2004), and John Swales (2004) study the genres of power in schools and other institutions and systems and share that genre knowledge

4 Again, this ideological perspective is particularly emphasized in Luke (1996), Peters (1997), and the collection by Coe et al. (2002); but also Beebee (1994) and Randazzo (2015). 
with outsiders to help them gain access to institutions from which they might otherwise remain excluded.

Genres matter not just as gatekeepers but also as enforcers. Every genre carries with it sets of not just formal expectations but also cultural ones, worldviews. Genres have developed out of the values, beliefs, and norms of those in power within the community, institution, and culture. They enforce, as Miller (1984) said, "what ends we may have." Tax accountants in the United States are governed by the Rules and Regulations of the Internal Revenue Service Tax Code; so tax accounting genres defer, refer, and accede to that code. In colleges and universities in the US, Aristotelian logic, evidence, and argument are highly valued, as reflected in their genres of research papers, literary analysis, and thesis-support argument papers, among many others. Scientists believe in research based on established methods, data, and replicable experiments, as reflected in their scholarly articles. Scientific scholarly articles ground their topics in prior research, present their methods, data, and results in clearly distinct sections, and claim only what the data support, with any speculation or implications explicitly labeled as such and heavily hedged. Their students' lab reports similarly describe their methods meticulously, their data in quantified charts and graphs, and their conclusions with ample qualifications and explicit limitations. Operating out of a different culture and worldview with different expectations, politicians value, among other things, followers, visibility, and inclusion in media; hence the passionately delivered speeches with rallying cries and the frequent media interviews containing pre-written sound bites. Genres reflect the values and worldviews of their users, and to use the genre is to accept those values and worldviews.

That acceptance might, however, be unwitting. New tax accountants might not recognize their obedience to the tax codes; new politicians might not see themselves as catering to the media. These novices might just be doing what tax accountants and politicians do. Few students learning to write a research paper probably recognize that they are learning to think like their professors. Some might recognize that they are writing to please a professor ("just tell me what you want"), but some of those students might be horrified if they recognized that in writing to please their professor, they are practicing being like their professor. Students writing a lab report more likely understand that they are taking labs to learn how to conduct an experiment like a scientist, to learn the scientific method; but they learn how to be a scientist through the lab report write-ups as well, learning to write like a scientist. The scientific method includes not just controlling for variables or adding this chemical before that one, but also taking detailed notes during the process, articulating hypotheses, and dis- 
tinguishing results from interpretation ${ }^{5}$. Since the values underlying a genre remain largely unstated, taking up the genre takes up those values unaware and uncritically ${ }^{6}$.

That genres carry with them unstated assumptions and values applies to their shaping effects on readers as well as composers. Scientific articles position readers to accept the importance of method, the requirement of data, and the limitations of results. Research papers invoke readers who expect logic and evidence, and the genres of tax accountants assume shared belief in the authority of the IRS Rules and Regulations. Without conscious awareness of genres' effects, readers and writers can find themselves inculcated into worldviews they might well have resisted.

But both writers and readers can get it wrong or can deliberately misconstrue, and genre's power to enforce its norms and values has limits (Freadman, 2014; Fuller \& Lee, 2002). Writers new to lab reports often mix results, discussion, and conclusions. Student researchers frequently make unsubstantiated statements in their research papers and unwarranted claims in their arguments. Readers of arguments may miss unwarranted claims. Clients receiving a letter from their tax accountant may not recognize that the advice isn't a legal opinion. Readers of scientific reports may, intentionally or unintentionally, miss the limitations or the validity (Smart \& Falconer, this volume) of the methods used, not heeding the importance of that genre feature.

Genres in different systems may have clashing values and purposes as well ${ }^{7}$. Journalists reporting on a scientific scholarly article about climate change may exaggerate the scientist's claims, since the news reporters have their own genres with their own values to reflect, like starting with a catchy lede, holding readers' attention, and presenting the news-worthy facts. Politicians may translate the scientific research article into their own genres of sound bites, campaign speeches, legislation, and, increasingly, tweets, all carrying the values of politicians rather than those of the original scientists. Activists and protesters may similarly reduce carefully worded implications in scientific articles to a few words on a poster (as in the protest sign described in the introduction to this volume). The implications of those scientific articles might even become extended to whole universes by writers of speculative fiction, dystopian novels, and cli-fi, with their own motivations and values.

So genres matter. Genres reflect, shape, and reinforce worlds through the social actions they define and perform. Genres carry with them values and norms that, like other ideologies, typically remain largely invisible or unnoticed, and sometimes overlooked. Especially because they are unnoticed, those values, norms, and actions shape readers and writers of genres - that is, all of us in all our interactions. Whether intentional or unintentional, knowing or unknowing, readers and writers then

5 See Schryer (1999) on the experimental article as a shaper of perceptions of time and space.

6 For example, see Bawarshi (2000) on "The Genre Function" and Bastian $(2010,2017)$ on the difficulty of disrupting that genre effect.

7 See Russell (1997), Winsor (1999), and Bazerman (2004) for more on activity system theory. 
attempt to shape others through their choice and use of genres and the values they perform. Becoming aware of genres' effects enables deliberate, conscious, and critical use of genres ${ }^{8}$. Becoming critically aware allows turning genres as social action into genres for social action.

\subsection{Genres for Social Action}

Genres work for social action rather than only as social actions when people act through them deliberately, consciously, and toward desired social ends. Genres work for social action when communicators actively choose and manipulate the genres they use rather than be used by them. Critical awareness of and deliberate work through genres can transform everyday social actions that get things done in the world into powerful actions with social and political purpose, actions meant to alter the world in meaningful and even structural ways.

I see at least four ways that users can act through genres for deliberate social purposes, for social action:

- Genre mindfulness - choosing genres that reflect and reinforce desired worldviews

- Genre resistance - resisting genres that reinforce undesired perspectives

- Genre revision - revising genres to better perform desired actions

- Genre creation - creating new genres to fulfill different purposes and instill different worldviews

These four genre actions can shape what people believe and how they behave. They can, in short, influence people, and they can do so in ways both subtle and dramatic.

One of the clearest sites for studying how genres operate for deliberate and transformative social action is in political debate and social activism. There the role of genres in resistance and the ability to resist genres becomes most deliberate and most visible. The chapters in this volume offer their own illustrations of the roles of genres in the climate debate. In the rest of this chapter, I will briefly sketch some examples of how those four categories of genre actions can influence public debate and activism.

\subsection{Genre Mindfulness}

Of course, I would prefer that every writer and reader in every situation were critically aware and choosing genres deliberately. Such constant deliberate choosing would surely slow down our operating in the world since we would no longer act automati-

8 As I argue in “Teaching Critical Genre Awareness” (Devitt, 2009b) and elsewhere. 
cally in ways we have been trained to act. But it would also create much more mindful interaction. Such mindful deliberate genre choice - genre mindfulness - can be especially effective when trying to influence others. As participants debate the existence, importance, or necessary responses to climate change, the most persuasive may well be those who choose strategies deliberately through choosing strategic genres.

Consider just a few of the many genres designed specifically for social activism, to influence legislators or public opinion - petitions, political cartoons, protest signs, public forums, sit-ins, rallies, marches, letters to the editor, op-eds, opinion columns. Such activist genres promote a culture of public responsibility, of valuing collective action as well as instilling power in individual action. At the same time, each activist genre acts differently, motivating different individual performances, targeting different audiences and using media - and news media - in different ways. Holding a protest sign at a 2017 People's Protest March in Washington saying “There is No 'Planet B' No EPA Cuts!!” (Levenson, 2017) is a different action from writing a letter to the editor of the local newspaper Lawrence Journal World in Kansas on "Climate awareness" (Boos, 2017). Choosing a genre chooses strategies and tactics grounded in different societal purposes and values.

Moving activist genres into digital spaces alters traditional genres even as they might be used for similar purposes. Activist political sites like moveon.org promote and distribute online petitions, offer cut-and-paste templates for writing to corporations, and provide talking points and phone numbers to ease the process of calling legislators. An online petition to fight climate change by stopping fracking of fossil fuels acts differently from a petition to stop fracking presented to grocery shoppers in Oklahoma as they leave the store. In addition to genres designed for activism, other existing genres online can be turned toward transformative social action. Social media create multiple platforms for activism, as well as for viral videos and trolling. For example, hashtags and tagging on Twitter, Instagram, Facebook, Snapchat, and newer emerging social media can become political and activist statements: \#climatechange is one example at this moment of promoting a hashtag to raise awareness and call for action. Facebook pages, including current ones like NASA Climate Change, can serve as sources of information, but that same genre can be used to promote particular agendas like climate change denial (for example, pages like the current version of Climate Change Discussion). Tweets can promote neutral or civil discussion of important weather events, or they can turn uncivil to promote a political position (Anderson \& Huntington, 2017). Existing broad genres can narrow to focus on influencing others - for example, science blogs geared toward political action, campaign and other speeches, and even parody and satire, including news satire. Change to: Leighann Thone's study of the television show of the television show Last Week Tonight demonstrates how John Oliver turned passive viewers of news satire shows into political activists, rallying them to use hashtags, write emails and make phone calls, even send money to make political and social points. On an early show from 2014, Oliver presents the science behind climate change and then makes a politi- 
cal point visible by staging a "mathematically representative climate change debate" - with three climate skeptics and a room full of scientists waving research papers and shouting scientific research - to demonstrate that the scientific debate is settled (Last Week Tonight, 2014), a performance that one study demonstrated affected viewers' beliefs in global warming (Brewer \& McKnight, 2017).

There's nothing new about the existence of activist genres and the ability to use media for activist purposes. But recognizing that genres carry with them values and worldviews, seeing that genres enable or limit particular social actions, such genre mindfulness makes choosing a particular genre a political as well as social act.

\subsection{Genre Resistance}

That same conscious awareness can lead as well to deliberately resisting genres whose purposes, values, and worldviews conflict with one's own. Resistance can take many forms, from ignoring a genre to countering it with a different genre, and options in between. At its core, genre resistance is a refusal to take up an existing genre, a resistance to acting within it as either reader or writer, consumer or composer. On one end of resistance, for example, critical awareness of news reports as a genre might lead some readers to resist them as sources of scientific information, about climate change or any other potentially hot topic. Some news reports value a sexy lede, so the initial claims might be taken with some skepticism. News reports also work to make information accessible to a wide audience, including those less educated about scientific topics, so readers seeking more complex understandings might look to other genres. News reports consider some facts and statements more newsworthy than others, so genre-aware readers might assume that some scientifically important or at least relevant facts are probably omitted. All genres have their biases and particular purposes. Genre-aware readers can use that fact to seek the genres they need and resist the genres they don't.

Both readers and writers can resist genres. Scientists report their results in scientific articles rather than news reports not only because that's the norm but because the genre fits their values and worldview: scholarly articles support fuller reporting, encourage detailed accounts, and require inclusion of all relevant information, appropriately hedged. When scientists venture into other genres to reach a broader audience, they can meet both their own and readers' resistance. A writer of a textbook like Jeffrey Bennett, writing A Global Warming Primer: Answering Your Questions About The Science, The Consequences, and The Solutions, may do an excellent job of presenting scientific information and receive mostly rave reviews on Amazon, but he still may find his emphasis on scientifically sound information derided sarcastically by online reviewers and recategorized as a "cult pamphlet."

Even as they wish to reach more open readers and potentially affect public debate, scientists writing popularizing books may find that genre conflicting with their values 
as scientists, a conflict that may lead to their resisting the popularizing genre. Writers of trade books like Malcolm Gladwell, Stephen Pinker, Neil deGrasse Tyson, Daniel Kahneman and others have shown how to adapt expert knowledge to the genre. They lead with anecdotes or illustrative stories instead of previous scholarship in order to gain readers' interest. The limitations of different methodologies may be ignored in favor of clearer conclusions. Complexities sometimes appear in notes at the end of the book instead of in the body. Environmental scientists like Stephen H. Schneider in Science as a Contact Sport: Inside the Battle to Save Earth's Climate or Paul Epstein MD and Dan Ferber in Changing Planet, Changing Health might adopt that genre's strategies but, given their training, values, and identities, still resist the genre in ways that keep them from reaching as many readers as a journalist like Jeff Goodell in The Water Will Come: Rising Seas, Sinking Cities, and the Remaking of the Civilized World, who more easily submits to the genre by telling stories and including personal experience. That is not to say that those scientific trade books are bad, wrong, or false. But they serve different ends and derive from different values.

The same is true for scientists who report their results in science blogs, tweets, LinkedIn or other professional connectors. Each genre embodies different values and perspectives and shapes the writer's information in different ways, some of which suit the writer's values and some of which the writer or readers might resist. Being aware of those generic differences can minimize surprise when a tweet is misunderstood, a blog or trade book receives harsh comments, or a professional post is reduced to its simplest application. Some writers might find that the trade-offs are too great, that a genre conflicts too deeply with the writer's values and motivations. For them, one option is to refuse to write such public genres, just as readers unwilling or unable to listen to scientific research might refuse to read more scientifically complex genres.

For social activists in particular, resisting a genre though ignoring it might not be enough. Stronger genre resistance might mean not simply ignoring a genre but actively introducing another existing genre into the conversation. When university lectures are seen as ideological propaganda (for example in campus speeches by white supremacist Richard Spencer and many others), activists might choose to resist the genre by ignoring the lecture and not attending, but others might confront that genre with protest signs, chants, shouts, and other disruptive genres. At my own university, students resisted a town forum on race led by a former Chancellor, one designed to allow members of the university community to share their experiences and difficulties with race on campus. While the Chancellor attempted to lead an orderly forum with individuals taking turns to tell their stories in polite language and respectful voices, a group of student activists took over the front of the stage with their own signs, loud chants, impassioned spokesperson, and a list of demands for action. Citing a history of calm discussions that had led to no change, the organizers resisted the purpose and values of the respectful town forum by inserting into it the genre actions of protest, rallies, and demands. 
Resisting genres, then, is also choosing genres. Resisting a genre may mean choosing not to write or read it - avoiding fake news or sensationalized reporting, for example. Resisting a genre may mean adding to it other genres - seeking out the original scientific articles behind the news report, health newsletter, or viral Facebook post. Resisting genres can also mean offering alternative genres - countering fake news with fact checking, meeting inflammatory political speeches with protest signs, or writing critical reviews of books. As Paré (2002) has noted, such restistance to a genre's worldview can create chinks through which the need for genre change becomes more visible.

\subsection{Genre Revision}

Using genres for social action does not require either accepting genres as they are, with whatever values and worldviews they might reflect and reinforce, or substituting wholly different genres. Writers constantly revise genres, every time they compose a new and hence unique performance of it (Devitt, 2009a). For deliberately transformative social action, writers can revise genres deliberately toward those purposes, and communities working together can change a genre toward their own ends.

Unfortunately, revising genres to perform actions differently has become a specialty of some who wish to exploit the public's general lack of genre awareness. Notice that many political speeches, in their action to rally supporters and gain media coverage, have become more focused on generating anger and resentment of others, a move supporters might not initially have noticed and may now accept as the new norm. News reports from many sources have exploited viewers' and readers' dependence and perhaps gullibility to revise news reports into biased and often inaccurate accounts, drastically altering the previous values of the genre (and probably creating a different, emerging genre, one that looks superficially like a news report but serves partisanship rather than accuracy and values viewership over integrity). While journalists for long-established newspapers like The New York Times and The Washington Post (among many, many others) are fighting against this change in news genres, the actions to change those genres are already so well in place that "fake news" may well be its own genre, a revised version of news reports with different values and purposes which journalists can now only resist, not revise (see Tandoc et al. (2017) for a typology of "fake news"). Charles Bazerman details the manipulation from multiple spheres and genres that made their way into government reports, websites, and proposals (Bazerman, 2010). Other genres on platforms previously geared toward social sharing, like Facebook and other social media, have been revised by trolls and haters toward conflict, leaving posters feeling genuine hurt and shock when replies contain personal attacks and verbal assaults. The abuse of these genres, along with the manipulation of public opinion through fake news posts, has led the CEOs of Facebook and other social media corporations to revise the genres themselves, largely 
in response to social activists' genre resistance. Genres always change as people use them differently, but not always for the better.

With so many obvious examples of genres being revised for fraudulent and socially unjust purposes, I'd like to offer a quite different and more positive example, a less visible but even more powerful means of performing genre revision by silently refusing to follow the genre's rules even while acting within it. In the United States legal courts, the action of jury nullification revises the genre of jury verdicts in ways that have significant impact on the legal system. According to the legal system, the jury's duty is to return a verdict based solely on the evidence and the law presented. But juries have been known to reject that constraint when they view the law as unjust or the evidence as unfair. In jury nullification, the members of a jury in a trial system decide on a verdict in a way that values their own sense of rightness or justice over that of the law. Jury nullification has been used deliberately to make a comment about a social issue or a particular law, and it has been used to right a perceived wrong. Whether refusing to convict those who illegally liberated or harbored slaves in the $19^{\text {th }}$ century or those who illegally assisted euthanasia in the $20^{\text {th }}$ century, in voting for a verdict based on their own sense of justice, juries are rejecting the legal values inherent in the verdict; they revise the verdict to be an action that values justice instead. Such dramatic revisions of a genre are rare, I suspect, but jury nullification provides an especially dramatic illustration of how a genre can be revised for social action through quieter means with even more impact. Although not yet applied, as far as I know, to the climate change debate or to its laws, resolutions, pacts, agreements, or executive orders, the illustration of jury nullification demonstrates that genres might be revised into actions with quite different values and purposes without necessarily calling public attention to that action.

Revising genres for social action thus requires both recognizing a flaw in the existing genre's purposes or values and acting on that recognition by changing the genre. As these examples illustrate, though, what seems a flaw to some might be an important value to others. Genre revising for transformative social action can rarely, if ever, be achieved alone. The trick to revising genres for social action successfully is twofold: making changes oneself and through one's communities that better serve desirable ends and reinforce desirable values; and others accepting those changes. Revisions can happen subtly, over time, creeping far into the norm before being noticed. Some "news" channels began sensationalizing the news early on, with so many viewers apparently approving of the change that their viewership increased. Other news channels resisted the change in the genre at first, but their conflicting values - accurate reporting versus high ratings - left many succumbing in the end. Voters who resisted the move to stir up anger and hostility stopped listening to those versions of political speeches and sought others to follow, but the strength of the genre's need to motivate voter response left a paucity of alternatives. Genre revision for socially corrupt ends can happen more easily with an unaware public, whose lack of genre resistance becomes acceptance. 
Of course, the situation is more complicated than I've described, especially for changing a genre oneself. Most significantly, these genres interact with other genres and especially with genres in other systems, so the forces encouraging or inhibiting change or resistance are multiple and complex. In the case of argument and debate about political issues, media systems and their genres strongly influence political systems and politicians' genres. Rather than creating change on their own, individuals are enmeshed in systems of power and institutional control that cannot simply be ignored without consequence (see Russell, 1997). In fact, it is the interactions of those systems that may create the cracks and chinks that make visible the need for genre change (Paré, 2002). Such clashing systems may have led to changes in scholarly articles in the humanities and social sciences, creating alternative versions of the genre. In scholarly articles, the genre's distancing and "objectivity" began to clash with feminist scholars' valuing of the personal, with feminist, cultural, and qualitative researchers' insistence on the importance of positionality, and with other philosophies' questioning of objectivity. These more particular communities of scholarly research held values and had purposes sometimes at odds with the action of scholarly articles. In some of those communities today, scholarly articles have normalized such values as researchers identifying their positions, including personal anecdotes and accounts, and valuing the voices of study participants as well as researchers. In turn, that revised genre effects changes in the values instilled in new researchers as they learn to write scholarly articles. The revised social action of scholarly articles thus offers new possibilities for transformative social action.

Interconnected and interacting systems of genres thus create space for revising genres for different and powerful social actions, which then reinforce those new actions in others. Genre-aware social activists might do well to seek out spaces where conflicting systems come together, perhaps in digital spaces or newly emerging alliances; to recognize which existing genres represent conflicting values or purposes; to deliberately act to revise those genres toward desired motives and ends; and to spread those revised genres among others in their networks. One simple example might already be visible on Twitter. On that social media platform, like-minded followers of one another have found that their tweets, previously valued for cleverness, humor, and information sharing, are coming into contact with tweets valued for overstatement, capitalized yelling, and ad hominen attacks. In this space of conflicting systems with conflicting values, movements have emerged to change the action of retweeting (sharing others' tweets with your followers) into a practice reserved only for tweets whose values you share rather than ones that are interesting in other ways. To make that process easier to achieve, hashtags like \#ClimateAction have been added to identify those of like minds, rather than using hashtags to identify common topics or add humor. That clash of systems on Twitter created a visible chink through which to see how the genre needed to change. Through that awareness, participants were able to revise the genres to better fit newly defined purposes and more strongly reinforce the community's values, then encouraging others to take up the genre in revised 
form. Whether the creators and executives behind those social media platforms will take even stronger action to support similar changes remains to be seen.

Once those interacting systems make visible potential clashes of values and purposes, all three strategies of using genres for social action are available. Some might revise the genres, as I've just illustrated, a move that in its extreme, as jury nullification makes clear, can wholly replace an existing genre's worldview. Others might resist the clashing genre rather than revise it, working to ignore it or counter it with other genres, while others might resist the genre and clamor for institutional genre revisions. And others, mindful of a genre's action, might simply choose different genres, walking away from tweets or even all social media, for example, and seek other genres that better fit their needs and values. In the search for other genres that work for desired social actions, a fourth action is sometimes possible - creating new or hybrid genres.

\subsection{Genre Creation}

Genres rarely appear as new because their origins can usually be seen in previously existing genres (Fowler, 1982; Jamieson, 1975). An exception might well be when new technology creates new media genres with new affordances (Giltrow \& Stein, 2009; Miller \& Kelly, 2017; Miller \& Shepherd, 2004), though even those emerging genres might credibly be viewed as revising existing genres for those new media rather than creating something wholly new. Although the creation of a wholly new genre would seem impossible, since new genres are always already grounded in existing genres, one way of using genres for transformative social action is to perform what seems to be an action not already available, to create a seemingly new genre for new purposes and values. These alternative genres might emerge out of existing genres stretched far beyond their original actions, out of hybridizing two or more existing genres, or, potentially, out of claiming a wholly new social action that calls for a wholly new genre label (see Nyboe (2016) on the importance of genre signatures and what a writer calls a genre).

The genre of news satire might be a case of hybridizing two existing genres to create something new. When Jon Stewart and others began satirizing current events through apparent nightly news shows, they were turning news shows to serve the actions of satire. The resulting genre performed a social action not achieved by news or satire alone. Parodies existed, of course, but news satire did more than parody news. The case of John Oliver's Last Week Tonight, mentioned earlier, stretched the genre even further toward not just social satire but social activism.

Some literary genres may be cases of genres claiming new labels in order to perform new actions. The genre of climate fiction or cli-fi, for example, is sometimes a stretching of speculative fiction, but not necessarily. Cli-fi might seem a narrowing of dystopian fiction, but again not necessarily. It might be seen as a hybrid of science 
and fiction or of many more genres, but it has become a genre with its unique social action around a shared topic (Bildsøe, 2016). So it does seem possible that newly described genres can develop toward new social actions. Whether traceable to existing genres explicitly or not, the point is that genres can be developed with particular social actions as their purposes and can be added to the genres available for transformative social action.

\subsection{From Critical Awareness to Positive Action}

To create genres for social action is not necessarily to create positive social actions. Genres can be used for good or evil, in simple terms, but they too often are perceived as only constraining rather than also enabling (Devitt, 2004a). Becoming aware of genres as social actions and becoming attentive to their underlying values and worldviews can lead to conscious use of genres for transformative social action - whether using genres for one's own desired actions or resisting the genre actions of others. I've outlined four means of turning genres toward social actions - genre mindfulness, genre resistance, genre revision, and genre creation - but each of those (and variations that likely will appear to future scholars) can be used to manipulate as well as to persuade. In intense political debates, in arguments about significant world issues, these capacities of genres must be noticed, critiqued, called out, and reformed. Such debates are too important to leave to those who effectively manipulate genre actions to those who choose genres that will influence others unconsciously, who resist genres of transparency and reason, who revise existing genres to mask motives or heighten the worst in people, or who create new genres to attack others. The fact that those manipulations seem the dominant ones at some political moments doesn't require giving up. In fact, it requires even more vigilance. If genres are to be used for purposeful social action, conscious awareness of how they operate and alertness to change in progress are the best defenses. (Of course, those are my own values as an academic and intellectual, one who has faith in reason and believes in the inherent rationality of human behavior. Those values and beliefs have certainly been challenged by some events and, in fact, by much of human behavior throughout our species' history.)

With my beliefs and values - and idealism, perhaps - intact, though, I also see people using genres for respectful debate and positive action. I see more people more frequently choosing genres of marches, rallies, protest signs, public forums, petitions, organized letter campaigns, and phone calls to decision makers. I see more active resistance to fake news, viral videos, and trolling, and I see more deliberate revision of tweets, hashtags, and fact checking to create positive alternatives. In short, I see more conscious awareness of genres' effects on beliefs as well as actions and more deliberate use of genres in response.

Once you see how genres are social actions, you should see how genres can be used for social action. Once you see genres as ideological and value-laden, you should 
see how genres can instill and reinforce desirable as well as undesirable values and norms. I use the "you" here deliberately and knowingly. Along with others, I am arguing that scholars should not just critique but also act on that critique. Now is the time to turn to see genres not just as social action but for social action. It's not enough just to become aware that genres can be used for social action; it's time to do something about it.

\section{References}

Anderson, A.A., \& Huntington, H.E. (2017). Social media, science, and attack discourse: How Twitter discussions of climate change use sarcasm and incivility. Science Communication, 39(5), 598-620. doi:10.1177/1075547017735113.

Artemeva, N. (2009). Stories of becoming: A study of novice engineers learning genres of their profession. In C. Bazerman, A. Bonini, \& D. de C. Figueiredo (Eds.), Genre in a changing world (158-78). WAC Clearinghouse; Parlor Press.

Auken, S. (2015). Utterance and function in genre studies: A literary perspective. In J. Andersen (Ed.), Genre theory in information studies (155-78). Bingley: Emerald Group Publishing Limited. doi:10.1108/S2055-537720140000011009.

Bakhtin, M.M. (1986). The problem of speech genres (V.W. McGee, Trans.). In C. Emerson \& M. Holquist (Eds.), Speech genres and other late essays (60-102). Austin: University of Texas Press.

Bastian, H. (2010). The genre effect: Exploring the unfamiliar. Composition Studies, 38(1), 27-49.

Bastian, H. (2017). Student affective responses to "Bringing the funk" in the first-year writing classroom. College Composition and Communication, 69(1), 6-34.

Bawarshi, A. (2000). The genre function. College English, 62(3), 335-360. doi:10.2307/378935.

Bawarshi, A.S., \& Reiff, M.J. (2010). Genre: An introduction to history, theory, research, and pedagogy. West Lafayette, Ind.: [Fort Collins, Colo.]: Parlor Press; WAC Clearinghouse.

Bazerman, C. (1994). Systems of genres and the enactment of social intentions. In A. Freedman \& P. Medway (Eds.), Genre and the new rhetoric (79-101). London: Taylor \& Francis.

Bazerman, C. (2004). Speech acts, genres, and activity systems: How texts organize activities and people. In C. Bazerman \& P. Prior (Eds.), What writing does and how it does it (309-339). Mahwah, N.J: Lawrence Erlbaum.

Bazerman, C. (2010). Scientific knowledge, public knowledge, and public policy: genred formation and disruption of knowledge for acting about global warming. Linguagem em (Dis) curso, 10(3), 445-463.

Beebee, T.O. (1994). The ideology of genre: a comparative study of generic instability. University Park, Pa.: Pennsylvania State University Press.

Bennett, J. (2016). A global warming primer: Answering your questions about the science, the consequences, and the solutions. Boulder, Colorado: Big Kid Science. https://www.globalwarmingprimer.com/primer/.

Berkenkotter, C., \& Huckin, T.N. (1995). Genre knowledge in disciplinary communication: cognition/ culture/power. Hillsdale, N.J: L. Erlbaum Associates.

Bhatia, V.K. (1993). Analysing genre: Language use in professional settings. London; New York: Longman.

Bildsøe, H. (2016). Into an age of cultural contagion: Vampiric globalisation in Mudrooroo's Master of the Ghost Dreaming Series. Coolabah, (18), 38-52. 
Boos, K., \& Lawrence. (2017, December 12). Letter to the editor: Climate awareness. Retrieved February 11, 2018, from http://www2.ljworld.com/news/2017/dec/12/letter-editor-climateawareness/

Brewer, P.R. \& J. McKnight (2017) “A statistically representative climate change debate”: Satirical television news, scientific consensus, and public perceptions of global warming. Atlantic Journal of Communication, 25:3, 166-180. doi:10.1080/15456870.2017.1324453.

Campbell, K.K., \& Jamieson, K.H. (1978). Form and genre: Shaping rhetorical action. Speech Communication Association, 5205 Leesburg Pike, Falls Church, Virginia.

CNN, E.L. (April 29, 2017). Climate protest takes on Trump's policies. Retrieved February 11, 2018, from https://www.cnn.com/2017/04/29/us/climate-change-march/index.html.

Coe, R.M., Lingard, L., \& Teslenko, T. (Eds.). (2002). The rhetoric and ideology of genre. Cresskill: Hampton Press.

Devitt, A.J. (1991). Intertextuality in tax accounting: Generic, referential, and functional. In C. Bazerman \& J. Paradis (Eds.), Textual dynamics of the professions: Historical and contemporary studies of writing in professional communities (335-357). Madison WI: University of Wisconsin Press.

Devitt, A.J. (2004a). Creative boundaries: An argument for genre as standard, genre as muse. In Writing Genres (137-162). Carbondale IL: Southern Illinois University Press.

Devitt, A.J. (2004b). Writing genres. Carbondale IL: Southern Illinois University Press.

Devitt, A. (2009a). Re-fusing form in genre study. In J. Giltrow \& D. Stein (Eds.), Genres in the Internet (27-47). Philadelphia: John Benjamins Publishing Company. doi:10.1075/pbns.188.02dev.

Devitt, A.J. (2009b). Teaching critical genre awareness. In C. Bazerman, A. Bonini, \& D. de C. Figueiredo (Eds.), Genre in a changing world. Fort Collins, Colo.; West Lafayette, Ind: WAC Clearinghouse; Parlor Press.

Epstein, P.R., \& Ferber, D. (2011). Changing planet, changing health. Berkeley, California: University of California Press.

Fowler, A. (1982). Kinds of literature: An introduction to the theory of genres and modes. Cambridge, Mass: Harvard University Press.

Freadman, A. (1994). Anyone for tennis? In A. Freedman \& P. Medway (Eds.), Genre and the new rhetoric (43-66). London: Taylor \& Francis.

Freadman, A. (2002). Uptake. In R. Coe, L. Lingard, \& T. Teslenko (Eds.), The rhetoric and ideology of genre (39-53). Cresskill: Hampton Press.

Freadman, A. (2014). Where is the subject? Rhetorical genre theory and the question of the writer. Journal of Academic Language and Learning, 8(3), A1-A11.

Freedman, A. \& P. Medway (Eds.) (1994). Genre and the new rhetoric. London: Taylor \& Francis.

Fuller, G., \& Lee, A. (2002). Assembling a generic subject. In R. Coe, L. Lingard, \& T. Teslenko (Eds.), The rhetoric and ideology of genre (207-224). Cresskill: Hampton Press.

Giltrow, J., \& Stein, D. (Eds.). (2009). Genres in the Internet: issues in the theory of genre. Amsterdam; Philadelphia: John Benjamins Pub. Co.

Goodell, J. (2017). The water will come: Rising seas, sinking cities, and the remaking of the civilized world. New York: Little, Brown and Company.

Hyland, K. (2004). Disciplinary discourses: social interactions in academic writing. Ann Arbor MI: University of Michigan Press.

Jamieson, K.M. (1975). Antecedent Genre as Rhetorical Constraint. Quarterly Journal of Speech, 61, 406-415. doi:10.1080/00335637509383303.

Johns, A.M. (1997). Text, role and context: Developing academic literacies. Cambridge University Press.

LastWeekTonight. (11 May 2014). Climate change debate: Last Week Tonight with John Oliver (HBO). Retrieved from https://www.youtube.com/watch?v=cjuGCJJUGsg. 
Luke, A. (1996). Genres of power? Literacy education and the production of capital. In R. Hasan \& G. Williams (Eds.), Literacy in society (308-338). London and New York: Longman.

Martin, J.R., \& Rose, D. (2008). Genre relations: Mapping culture. London and Oakville CT: Equinox Publishing.

Miller, C.R. (1984). Genre as social action. Quarterly Journal of Speech, 70, 151-167. doi:10.1080/00335638409383686.

Miller, C. R. (2017). Where do genres come from. In C.R. Miller \& A.R. Kelly [now Mehlenbacher] (Eds.), Emerging genres in new media environments (1-34). London: Palgrave Macmillan. doi:10.1007/978-3-319-40295-6_1.

Miller, C.R., \& Shepherd, D. (2004). Blogging as social action: A genre analysis of the weblog. In L. Gurak, S. Antonijevic, \& L. Johnson (Eds.), Into the blogosphere: rhetoric, community and the culture of weblogs. Minneapolis: University of Minnesota Libraries.

Miller, C.R., \& Kelly [now Mehlenbacher], A.R. (Eds.). (2017). Emerging genres in new media environments. London: Palgrave Macmillan.

Nyboe, J.Ø. (2016). The game of the name: Genre labels as genre and signature. Scandinavian Studies, 88(4), 364-392.

Paré, A. (2002). Genre and identity: Individuals, institutions, and ideology. In R. Coe, L. Lingard, \& T. Teslenko (Eds.), The rhetoric and ideology of genre (57-71). Creskill: Hampton Press.

Peters, B. (1997). Genre, antigenre, and reinventing the forms of conceptualization. In Genre and writing: Issues, arguments, alternatives (199-214). Portsmouth NH: Boynton/Cook.

Randazzo, C. (2015). Hearing silence: Toward a mixed-method approach for studying genres' exclusionary potential. Composition Forum, 31(Spring).

Russell, D.R. (1997). Rethinking genre and society: an activity theory analysis. Written Communication, 14(4), 504-554. doi:10.1177/0741088397014004004.

Schneider, S.H. (2010). Science as a contact sport: Inside the battle to save Earth's climate. Washington, D.C.: National Geographic.

Schryer, C. (1999). Genre time/space: Chronotopic strategies in the experimental article. JAC, 19(1), 81-89.

Segal, J.Z. (2007). Breast cancer narratives as public rhetoric: Genre itself and the maintenance of ignorance. Linguistics \& the Human Sciences, 3(1), 3-23. doi:10.1558/lhs.v3i1.3.

Swales, J.M. (1990). Genre analysis: English in academic and research settings. Cambridge [England]; New York: Cambridge University Press.

Swales, J.M. (2004). Research genres: Explorations and applications. Cambridge, UK; New York: Cambridge University Press.

Tandoc Jr., E.D., Z.W. Lim \& R. Ling (2017). Defining “fake news”. Digital Journalism, 6:2, 137-153, doi:10.1080/21670811.2017.1360143.

Thone, L. (2020). "Focus your indiscriminate rage in a useful direction": Understanding audience engagement and participation in the news satire genre. [Doctoral dissertation]. University of Kansas.

Winsor, D.A. (1999). Genre and activity systems: The role of documentation in maintaining and changing engineering activity systems. Written Communication, 16(2), 200-224. doi:10.1177/0 741088399016002003. 